\title{
PENGARUH HARGA DAN KUALITAS PELAYANAN TERHADAP KEPUASAN KONSUMEN PADA LFAMART JL. JAKSA AGUNG SUPRAPTO NO.11 MOJOROTO-KEDIRI
}

\author{
Ria Setia W; Sasi Utami; Sri Rochani \\ Fakultas Ekonomi - Universitas Kadiri \\ E-mail : sasi@unik-kediri.ac.id
}

\begin{abstract}
This study aims to analyze the effect of Price and Service Quality on Consumer Satisfaction on Alfamart Jl. Jaksa Agung Suprapto No.11Mojoroto Kediri. The problems in this study are (1) How Partial Influence of Prices on Consumer Satisfaction, (2) How Does the Quality of Service Partially Affect Consumer Satisfaction, (3) How Does the Price and Quality of Services All / Simultaneous to Satisfaction of Customers Affect The population of this study are all consumers of Afamart J1. Attorney General Suprapto No. 11 Mojoroto-Kediri. Samples are used with incidental and sampling techniques using the Rao Purba formula to obtain a sample of 100 respondents. The results obtained by the regression equation $\mathrm{Y}=2,914+0,502 \mathrm{X} 1+0,052 \mathrm{X} 2$. There is an influence between the price partially with the value $t=7.645$, there is the influence of service quality partially with the value of $t=3.162$, there is the influence of price and quality of service simultaneously with the value of $F=65,870$. Overall price and service quality affect consumer satisfaction by $57.6 \%$ while the remaining $34.13 \%$ is influenced by other variables besides price and service quality.
\end{abstract}

Keywords: Price, Service Quality, Consumer Satisfaction

\begin{abstract}
ABSTRAK
Penelitian ini bertujuan untuk menganalisis pengaruh Harga dan Kualitas Pelayanan terhadap Kepuasan Konsumen pada Alfamart J1.Jaksa Agung Suprapto No.11Mojoroto Kediri. Permasalahan dalam penelitian ini adalah (1) Bagaimana Pengaruh Harga Secara Parsial terhadap Kepuasan Konsumen, (2) Bagaimanakah Pengaruhnya Kualitas Pelayanannya Secara Parsial terhadap Kepuasannya Konsumen, (3) Bagaimanakah Pengaruhnya Harganya dan Kualitasnya Pelayanannya Secara seluruh/Simultan terhadap Kepuasannya Konsumen. Populasi dari penelitian ini adalah seluruh konsumen Afamart Jl. Jaksa Agung Suprapto No. 11 Mojoroto-Kediri. Sampel digunakan dengan teknik incidental dan penarikan sampel menggunakan rumus Rao Purba sehingga diperoleh sampel 100 responden. Hasil penelitian diperoleh persamaan regresi $\mathrm{Y}=$ $2,914+0,502 \mathrm{X} 1+0,052 \times 2$. Ada pengaruh antara harga secara parsial dengan nilai $\mathrm{t}=$ 7,645 , ada pengaruh kualitas pelayanan secara parsial dengan nilai $t=3,162$, ada pengaruh harga dan kualitas pelayanan secara simultan dengan nilai $F=65,870$. Secara keseluruhan harga dan kualitas pelayanan mempengaruhi kepuasan konsumen sebesar $57,6 \%$ sedangkan sisanya yaitu $34,13 \%$ dipengaruhi oleh variabel lain selain harga dan kualitas pelayanan.
\end{abstract}

Kata Kunci : Harga, Kualitas Pelayanan, Kepuasan Konsumen 


\section{PENDAHULUAN}

Perkembangan usaha saat ini tidak terlepas akan persaingan yang sangat ketat. Baik untuk perusahaan yang menawarkan jasa maupun barang. Semakin banyak perusahaan yang menawarkan jasa maupun barang,semakin banyak perusahaan yang terlibat dalam pemenuhan kebutuhan dan keinginan konsumen menyebabkan setiap perusahaan harus menempatkan orientasi pada harga dan kualitas pelayana terhadap kepuasan konsumen (Yunanto, 2017). Perusahaan berusaha memperebutkan calon pembeli dengan cara mempertahankan konsumen yang ada. Menurut Engel (1990, Tjiptono, 2008:24) sekurang- urangnya sama atau melampaui harapan konsumen, sedangkan ketidakpuasan timbul apabila hasil (outcome) tidak memenuhi harapan. Kepuasan konsumen dalam menggunakan produk atau jasa dipengaruhi oleh harga (Kristanti, 2018). Daya tarik produk atau jasa tidak dapat dilepaskan dari harga seperti uang, waktu, upaya perilaku, nilai dan penetapan harga. Jumlah dari nilai yang akan ditukarkan para pelanggan untuk memperoleh manfaat dari memiliki atau menggunakan suatu produk atau jasa.

\section{TINJAUAN PUSTAKA}

\section{Konsep Inti Pemasaran}

1. Kebutuhan

Konsep dasar yang melandasi pemasarn adalah kebutuhan manusia. Kebutuhan manusia adalah pernyataan dari rasa kehilangan, dan manusia mempunyai banyak kebutuhan yang komplek tersebut karena bukan hanya fisik (makanan, pakaian perumahan, dll.), tetapi juga rasa aman, aktualisasi diri, sosialisasi, penghargaan, kepemilikan.

2. Keinginan rasa yang muncul dari dalam diri kita akan sesuatu yang dibutuhkannya

3. Permintaan

Dengan keckinginan memuaskan perasaan

\section{Produk}

Karena semua perusahaan berusaha menawarkan produk dan jasa yang superior, maka konsumen dihadapkan pada pilihan yang beraneka ragam.

5. Kepuasan pelanggan 
Kepuasan pelanggan tergantung pada anggapan kinerja produk dalam menyearahkan nilai relative terhadap harapan pembeli.

6. Mutu

Kepuasan, jasa, dan proses pemasaran secara terus menerus.

\section{Perilaku Konsumen}

Menurut David L. Loundon dan Albert J. Bitta 1984 dalam (Agustina, 2011:40Faktor-faktor yang mempengaruhi perilaku konsumen menurut Rangkuti (2006:60), adalah :

1. Faktor budaya

2. Faktor social

\section{Kualitas Pelayanan}

Menurut Tjiptono dan Chandra (2011:115), kualitas pelayanan memiliki hubungan yang erat dengan kepuasan pelanggan, Kualitas Pelayanan memberikan dorongan kepada pelanggan untuk menjalin ikatan hubungan yang kuat dengan perusahaan.

Payne (2010:275) mendefinisikan kualitas pelayanan sebagai kemampuan sebuah organisasi memberikan pelayanan untuk memenuhi atau melebihi harapan pelanggan.

\section{Kepuasan Konsumen}

Kata kepuasan (Satisfaction) berasal dari bahasa latin "Satis" (artinya cukup baik,memadai) dan "fatio" (melakukan atau membuat). Kepuasan bisa diartikan sebagai "upaya pemenuhan sesuatu" atau "membuat sesuatu memadai" (Tjiptono dan Georgeus, 2007:195), Konsumen adalah seseorang yang menggunakan barang atau jasa yang telah dibelinya.

Kepuasan konsumen adalah rangkuman berbagai intensitas respons afektif. Tipe respons afektif dan tingkat intensitas yang mungkin dialami konsumen harus didefinisikan secara eksplisit oleh peneliti tergantung pada konteks penelitiannya (Tjiptono dan Georgeus, 2007:196). Philip Kotler dan Kevin Lane Keller (2007:177) kepuasan konsumen adalah perasaan senang atau kekecewaan seseorang yang muncul 
setelah membandingkan kinerja (hasil) produk yang dipikirkan terhadap kinerja yang diharapkan. Jika kinerja produk lebih rendah dari harapan, konseumen akan kecewa, jika ternyata sesuai harapan konsumen akan puas, jika melebihi harapan, pembeli akan sangat puas. Persaingan yang semakin ketat dimana semakin banyak produsen yang terlibat dalam pemenuhan kebutuhan dan keinginan konsumen, menyebabkan perusahaan harus menempati orientasi pada kepuasan konsumen sebagai tujuan utama (Tjiptono, 2008:24),menyatakan bahwa perusahaan perlu melihat pentingnya konsumen dipuaskan dengan memberikan harga yang relatif murah dan kualitas produk yang baik.

\section{Loyalitas Pelanggan}

Menurut tjiptono (2008:110) Loyalitas merupakan komitmen pelanggan terhadap toko, merek ataupun pemasok yang didasarkanatau sikap positif

\section{Metode Pengukuran Kepuasan}

Biasanya perusahaan melakukan beberapa pengukuran pada tingkat kepuasan konsumen yang bertujuan untuk mengetahui kemajuan perusahaan dalam kinerja dan pelayanan perusahaan. Hal tersebut menunjukkan bahwa adanya suatu bentuk kepedulian suatu perusahaan terhadap konsumen atau pelanggan. Menurut Kotler (2009:45)

\section{Manfaat Agar Terciptanya Kepuasan Konsumen}

Terciptanya kepuasan pelanggan yang merasa puas. Terciptanya kepuasan pelanggan dapat memberikan beberapa manfaat, diantaranya :

1. Hubungan antara perusahaan dan pelanggan menjadi harmonis.

2. Memberikan dasar yang baik bagi pembeli ulang.

3. Dapat mendorong tercieptanya loyalitas pelanggan.

4. Membentuk suatu rekomendasi dari mulut ke mulut yang menguntungkan bagi perusahaan.

5. Reputasi perusahaan menjadi baik dimata pelanggan.

6. Laba yang diperoleh dapat meningkat. 


\section{METODE PENELITIAN}

\section{Populasi dan Sampel Penelitian}

Populasi adalah Sugiyono (2014:148). Populasi dalam penelitian ini populasinya adalah konsumen Alfamart Jl. Jaksa Agung Suprapto No.11 Mojoroto-Kediri yang bersedia menjadi objeki penelitian dengan mengisi kuesioner yang telah dipersiapkan sebelumnya oleh peneliti. Karena jumlahnya tidak tetap, maka populasi dalam penelitian ini termasuk dalam kategori populasi infinit. Sampel menurut Sugiyono (2012:73) adalah bagian dari jumlah dan karakteristik yang dimiliki oleh populasi tersebut. Dengan kata lain sampel merupakan bagian dari produksi.

\section{Variabel Penelitian, Cara Pengukuran dan Definisi Operasional Variabel Penelitian}

variabel yang dianalisis dalam penelitian ini dapat dikelompokkan menjadi dua, yaitu variabel bebas (independent) dan variabel tergantung (dependent) yang mempunyai hubungan sebab akibat. Variabel bebas dalam penelitian ini adalah masingmasing Harga (X1) Kualitas Pelayanan (X2) sedangkan variabel terikat adalah kepuasn konsumen (Y1).

\section{Definisi Operasional Variabel}

Variabel beserta definisi operasional yang digunakan dalam pembahasan penelitian ini adalah sebagai berikut :

Harga (X1) : Indikator harga menurut Lupiyoadi (2006:98) yaitu : Keterjangkauan Harga (X1.1), Daya Saing Harga (X1.2), Kesesuaian Harga dengan Manfaat (X1.3) Kualitas Pelayanan (X2) : Indikator kualitas pelayanan menurut Parasuraman et al.(dalam Lupiyoadi dan Hamdani, 2009:182) yaitu : Bukti Fisik (X2.1), Keandalan (X2.2), Jaminan X2.3), Daya tanggap (X2.4), Perhatian (X2.5)

Kepuasan Konsumen (Y1) : Indikator kepuasan konsumen menurut boilding et al (1993) dalam Qin (2010) yaitu : Niat untuk pembelian ulang (Y1.1),

Merekomendasikan kepada konsumen lain (Y1.2), Melakukan pembeian Ulang (Y1.3)

Cara Pengukuran : Dalam penelitian untuk pengukuran variabel harga dan kualitas pelayanan dengamn menggunakan Skala Likert. Skala likert menurut Djalii (2008:28) 


\section{Metode Analisis Data}

\section{Analisis Regresi Linier Berganda}

Analisis regresi linier berganda untuk mengetahui bagaimana hubungan antara variabel menurut Sujarwen dan Indrayanto (2012:88) Model persamaan regresi linear berganda adalah sebagai berikut :

$$
\mathrm{Y}=\mathrm{a}+\mathrm{b} 1 \mathrm{X} 1+\mathrm{b} 2 \mathrm{X} 2+\mathrm{e}
$$

Keterangan :

$$
\mathrm{Y}=\text { Kepuasan Konsumen } \mathrm{a}=\text { Konstanta }
$$

b1,b2 = Koefisien regresi untuk masing-masing variabel bebas

e $\quad=$ Kesalahan pengganggu/error Model persamaan regresi linear berganda adalah sebagai berikut :

\section{HASIL PENELITIAN DAN PEMBAHASAN}

\section{Diskikripsi Penelitian}

\section{Lokasi Penelitian}

Penelitian ini dilakukan di Alfamart Jl. Jaksa Agung Suprapto. Alasan peneliti memilih Alfamart, Karena minimarket Alfamart merupakan salah satu jaringan minimarket pertama di Indonesia yang memperoleh sertifikat ISO untuk sistem manajemen mutu. Jumlah gerai mencapai 3000 gerai, karena memiliki jaringan retail terbesar dengan ribuan gerai yang tersebar hingga pelosok daerah menjadikan Alfamart pilihan belanja konsumen.

Dalam penelitian ini peneliti memilih Lokasi di Area Mojoroto-Kediri dengan pertimbangan menghemat biaya, tenaga, waktu, dan kemudahan dalam memperoleh responden.

\section{Waktu Penelitian}

Dalam proses penelitian ini membutuhkan waktu menjadi 3 langkah kegiatan yaitu meliputi :

1. Proses persiapan : Poses persiapan penelitian diawali dengan kegiatan mengidentifikasi permasalahan yang akan digunakan sebagai lokasi penelitian, perumusan masalah yang teridentifikasi, pengumpulan dasar teori yang memperkuat landasan dalam menemukan variabel, penyusunan hipotesa, penyusunan metode 
dalam pengumpulan data, penyusunan instrumen, hingga penentuan teknik pengujian statistik yang dipergunakan. Pada proses tahap persiapan ini dibutuhkan waktu selama satu bulan yaitu terhitung mulai tanggal 1- 31 Desember 2017 dan diseminarkan pada tanggal $27-02-2018$.

2. Proses pelaksanaan : Pada tahap proses pelaksanaan penelitian dimulai dari kegiatan penyusunan responden, penyampaian kuesioner kepada responden, tahap proses penelitian ini memakan waktu selama 1 minggu yaitu terhitung pada tanggal $02-09$ Januari 2018.

3. Proses pelaporan : Pada proses pelaporan dimulai dari kegiatan meng-edit dan memberikan kode data, memproses data, menganalisa dan menginterprestasikan hasil (output), kemudian diakhiri dengan penyimpulan hasil penelitian. Pada tahap proses pelaporan penelitian ini membutuhkan waktu satu bulan.

\section{Hasil Penelitian}

Beberapa tahun ini sejumlah penghargaan juga diraih Alfmart, seperti Top Brand Award dan Indonesia Brand Award 2009, yang mencerminkan pencapaian kinerja perseroan yang terus membaik. Selain itu, prestasi alfamart juga dapat dilihat dari jumlah gerai Alfamart yang terus berkembang pesat. Sebagai gambaran,per 31 desember 2008, Alfamart memiliki 2.157 gerai minimarket dan 622 minimarket Alfamart dalam bentuk waralaba. Angka ini terus berkembang dengan jumlah gerai per Mei 2009 mencapai 3.000 buah dengan gerai berbentuk waralaba sebanyak 711 buah yang tersebar di Pulau Jawa dan Sumatra.

\section{Tugas dan Fungsi Susunan Struktur Organisasi :}

1. General Manager

General Manager adalah pemimpin utama yang bertanggung jawab terhadap kemajuan dan perkembangan toko minimarket alfamart, general manager tidak berada di toko melainkan di kantor pusat PT. Sumber Alfaria Trijaya (SAT).

2. Deputy Branch Manager

Deputy Branch Manager bertanggung jawab terhadap Distribution center dan secara langsung atas operasional.

3. Area Manager

Area Manager bekerja 


\section{Kepala Toko (Chief Of Store)}

Kepala toko merupakan jabatan tertinggi dalam sebuah toko yang memiliki wewenang hampir mutlak tapi juga memikul tanggung jawab yang besar dalam mengelola sebuah toko.

\section{Hasil Uji Validitas}

\section{Hasil Uji Validitas X1 (Harga)}

\begin{tabular}{|c|c|c|c|c|}
\hline $\begin{array}{c}\text { Nomor Butir } \\
\text { Pernyataan }\end{array}$ & $\begin{array}{c}\text { Nilai r Hitung } \\
\text { (Pearson } \\
\text { Correlation) }\end{array}$ & $\begin{array}{c}\text { Nilai r Tabel } \\
\mathbf{N}=\mathbf{1 0 0} \\
\mathbf{a = 5 \%}\end{array}$ & Sig (2-Tailed) & Keterangan \\
\hline Item 1 & 0,903 & 0,194 &, 000 & Valid \\
\hline Item 2 & 0,812 & 0,194 &, 000 & Valid \\
\hline Item 3 & 0,715 & 0,194 &, 000 & Valid \\
\hline
\end{tabular}

Sumber : Data Primer Diolah (2018)

Berdasarkan hasil uji validitas pada dapat diketahui seluruh item pernyataan dari variabel harga mempunyai niai $r$ hitung $>$ dari $r$ tabel dan sesuai dengan ketentuan yang ditetapkan, maka hal ini berarti seluruh item pernyataan tersebut seluruhnya Valid dan dapat digunakan dalam penelitian.

\section{Hasil Uji Validitas X2 (Kualitas Pelayanan)}

\begin{tabular}{|l|c|c|c|c|}
\hline $\begin{array}{c}\text { Nomor Butir } \\
\text { Pernyataan }\end{array}$ & $\begin{array}{c}\text { Nilai r Hitung } \\
\text { (Pearson } \\
\text { Correlation) }\end{array}$ & $\begin{array}{c}\text { Nilai r Tabel } \\
\mathbf{N = 1 0 0} \\
\mathbf{a = 5 \%}\end{array}$ & Sig (2-Tailed) & Keterangan \\
\hline Item 1 & 0,598 & 0,194 &, 000 & Valid \\
\hline Item 2 & 0,674 & 0,194 &, 000 & Valid \\
\hline Item 3 & 0,747 & 0,194 &, 000 & Valid \\
\hline Item 4 & 0,519 & 0,194 &, 000 & Valid \\
\hline Item 5 & 0,728 & 0,194 &, 000 & Valid \\
\hline Item 6 & 0,770 & 0,194 &, 000 & Valid \\
\hline Item 7 & 0,791 & 0,194 &, 000 & Valid \\
\hline Item 8 & 0,799 & 0,194 &, 000 & Valid \\
\hline Item9 & 0,756 & 0,194 &, 000 & Valid \\
\hline Item 10 & 0,724 & 0,194 &, 000 & Valid \\
\hline Item 11 & 0,821 & 0,194 &, 000 & Valid \\
\hline Item12 & 0,703 & 0,194 &, 000 & Valid \\
\hline Item13 & 0,664 & 0,194 &, 000 & Valid \\
\hline Item 14 & 0,640 & 0,194 &, 000 & Valid \\
\hline
\end{tabular}

Sumber : Data Primer Diolah (2018)

Berdasarkan hasil uji validitas dapat diketahui seluruh item pernyataan dari variabel kualitas pelayanan mempunyai nilai $\mathrm{r}$ hitung $>$ dari $\mathrm{r}$ tabel dan sesuai dengan ketentuan yang ditetapkan, maka halini berarti seluruh item pernyataan tersebut seluruhnya valid dan dapat digunakan dalam penelitian ini. 
Hasil Uji Validitas Y (Kepuasan Konsumen)

\begin{tabular}{|c|c|c|c|c|}
\hline $\begin{array}{c}\text { Nomor Butir } \\
\text { Pernyataan }\end{array}$ & $\begin{array}{c}\text { Nilai r Hitung } \\
\text { (Pearson } \\
\text { Correlation) }\end{array}$ & $\begin{array}{c}\text { Nilai r Tabel } \\
\mathbf{N = ~ 1 0 0} \\
\mathbf{a = 5 \%}\end{array}$ & Sig (2-Tailed) & Keterangan \\
\hline Item 1 & 0,679 & 0,194 &, 000 & Valid \\
\hline Item 2 & 0,910 & 0,194 &, 000 & Valid \\
\hline Item 3 & 0,851 & 0,194 &, 000 & Valid \\
\hline
\end{tabular}

Sumber : Data Primer Diolah (2018)

Berdasarkan hasil uji validitas dapat diketahui seluruh item pernyataan dari variabel Kepuasan Konsumen mempunyai nilai $r$ hitung $>$ dari $r$ tabel dan sesuai dengan ketentuan yang ditetapkan, maka hal ini berarti seluruh item pernyataan tersebut seluruhnya valid dan dapat digunakan dalam penelitian ini.

\section{Analisis Regresi Linier Berganda}

Dalam melakukan analisis faktor harga (X1) dan kualitas pelayanan (X2) terhadap kepuasan konsumen (Y) Alfamart Jaksa Agung, digunakan analisis regresi linier berganda.

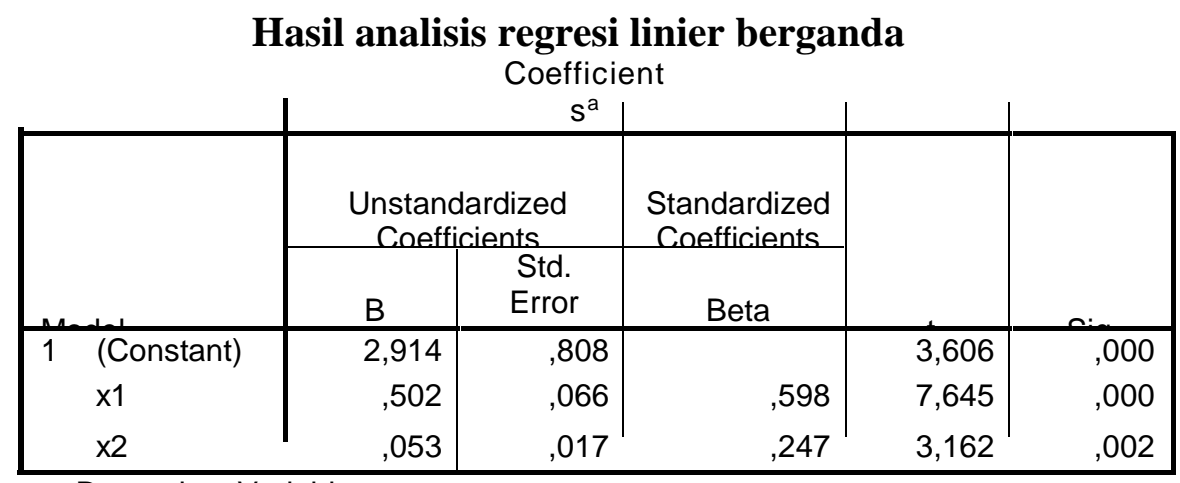

a. Dependent Variable: $y$

Sumber : Output SPSS versi 20

Berdasarkan tabel 4.16 maka dapat dijelaskan bahwa X1 = 0,502 dan X2 = 0,053 diperoleh persamaan regresi adalah $\mathrm{Y}=2,914+0,502 \mathrm{X} 1+0,052 \mathrm{X} 2$.

Persamaan regresi tersebut memiliki makna sebagai berikut :

1. Konstanta sebesar 2,914 artinya jika harga dan kualitas pelayanan dianggap tetap, maka kepuasan konsumen sebesar 2,914 poin.

2. Koefisien regresi $\mathrm{X} 1$ sebesar 0,502 artinya jika nilai harga mengalami kenaikan sebesar 1 (satu) poin sementara kualitas pelayanan diasumsikan tetap, maka akan menyebabkan kenaikan kepuasan konsumen sebesar 0,502. 
3. Koefisien regresi X2 sebesar 0,053 artinya jika nilai kualitas pelayanan mengalami kenaikan 1 (satu) poin sementara harga diasumsikan tetap, maka akan menyebabkan turunnya kepuasan konsumen sebesar 0,053.

\section{Pembahasan}

Berdasarkan hasil analisis data dari simultan dan uji parsial, dapat diketahui bahwa variabel harga dan kualitas pelayanan pada alfamart jaksa agung mempunyai pengaruh signifikan terhadap kepuasan konsumen yang dibuktikan dalam hasi uji analisis regresi. Hasil penelitian ini didukung oleh penelitian terdahulu yang dilakukan oleh Della Sabrica, dkk dengan judul Pengaruh Kualitas Pelayanan dan Harga terhadap Kepuasan Konsumen pada RM Kampoeng Djowo Sekatul Kabupaten Kendal yang menyatakan bahwa variabel kualitas pelayanan dan harga mempengaruhi kepuasan konsumen 36,3\% sedangkan sisanya 63,7\% dipengaruhi oleh variabel lain, selain kualitas pelayanan dan harga, penelitian ini juga didukungoleh penelitian yang dilakukan Eko Yuwananto dengan judul Pengaruh Kualitas Pelayan dan Harga terhadap Kepuasan Pelanggan pada toko bangununan "95" dengan hasil penelitian Kualitas Pelayanan dan Harga memiliki pengaruh yang signifikan terhadap kepuasan pelanggan. Besarnya pengaruh tersebut yaitu 70,8\% yang berarti bahwa kualitas pelayanan dan harga mempunyai pengaruh yang cukup besar terhadap kepuasan pelanggan.

Bentuk pengaruh dari harga dan kualitas pelayanan dengan kepuasan konsumen tersebut dapat digambarkan dengan persamaan regresi yang diperoleh nilai koefisien regresi yang bertanda positif, hal tersebut menunjukkan bahwa antar harga dan kualitas pelayanan mempunyai pengaruh positif terhadap kepuasan konsumen. Dengan demikian dapat dijelaskan bahwa jika variabel harga ditingkatkan satu point, maka akan diikuti dengan meningkatnya kepuasan konsumen. Jika kualitas pelayanan ditingkatkan satu point maka akan diikuti menurunnya kepuasan pelanggan. Oleh karena itu, untuk menjamin kepuasan konsumen dapat terwujud, salah satu upaya yang dapat dilakukan oleh Alfamart Jaksa Agung Suprapto No.11 Mojoroto-Kediri yaitu dengan menjamin harga yang sesuai dengan harapan konsumen, dan menjamin kualitas pelayanan untuk tetap baik, karena kontribusi dari harga dan kualitas pelayanan terhadap kepuasan konsumen cukup besar. 
Secara umum dapat diketahui bahwa Harga dan Kualitas Pelayanan merupakan faktor yang penting agar diperoleh tingkat kepuasan konsumen yang tinggi. Hal ini ditunjukkan dari hasil simultan yang diperoleh dari kedua variabel yaitu Harga dan Kualitas Pelayanan yang signifikan,yang berarti ada pengaruh antara Harga dan Kualitas Pelayanan terhadap kepuasan konsumen. Besarnya pengaruh dari kedua variabel ini cukup besar,yaitudibuktiktan pada pengujian koefisien determinasi dengan nilai $57,6 \%$. dan sisanya yaitu $42,4 \%$ dari kepuasan konsumen dipengaruhi oleh faktor lain yang tidak dikaji dalam penelitian ini.

Dari analisis harga yang disediakan oleh alfamart jaksa agung termasuk dalam kategori baik, hal ini dapat dilihat dari harga yang terjangkau, harga yang lebih murah dibanding pesaingnya dan harga sesuai dengan kualitas barang. Dalam penetapan harga perlu diperhatikan daya beli konsumen karena harga erat kaitannya dengan perspektif konsumen, pelanggan langsung merasakan perubahan harga yang ditawarkan. Hal ini sesuai dengan pernyataan Agustinta Shinta (2011:115) yaitu dengan menetapkan harga suatu produk dibawah biayanya. Tujuannya adalah untuk menarik konsumen supaya datang ke toko dan membeli pula produk-produk yang lain, khusunya produk-produk yang ber-markup cukup tinggi dan bukan untuk meningkatkan penjualan produk yang bersangkutan. Oleh karena itu dalam menetapkan harga perlu diperhatikan pula daya beli konsumen agar konsumen tidak beralih pada alfamart lain. Kenaikan harga yang dilakukan oleh alfamart jaksa agung dikarenakan adanya kenaikan harga dari pusat dan dikarenakan jumlah barang yang diminta lebih sedikit dibandingkan dengan stok produk yang ada, untuk mengimbagi hal tersebut agar bisa diterima oleh konsumen alfamart jaksa agung memperhatikan kualitas produk agar kenaikan tersebut tidak menjadi suatu bentuk kekecewaan dari konsumen.

Sedangkan kualitas pelayanan dapat diketahui bahwa pelayanan yang diberikan alfamart jaksa agung termasuk dalam kategori baik yang sesuai dengan pernyataan sebagian besar responden. Hal ini sesuai dengan pendapat menurut Tjiptono dan Chandra (2011:115) yang menyatakan bahwa kualitas pelayanan memiliki hubungan yang erat dengan kepuasan pelanggan, Kualitas Pelayanan memberikan dorongan kepada pelanggan untuk menjalin ikatan hubungan yang kuat dengan perusahaan. Dalam jangka panjang seperti ini memungkinkan perusahaan untuk memahami dengan seksama harapan pelanggan serta kebutuhan pelanggan. 
Menurut sebagian besar responden bukti fisik pada alfamart jaksa agung termasuk dalam kategori baik, hal ini dapat dilihat dari kondisi bangunan yang luas, kokoh dan lokasi yang strategis, adanya bukti transaksi, karyawan yang rapi dan papan nama toko yang terlihat jelas. Disamping itu alfamart jaksa agung juga cepat dalam melayani pembelian, cermat dalam menyelesaikan transaksi pembayaran dan juga tanggap dalam terhadap masalah yang dihadapi konsumen,. Jika dilihat dari aspek jaminan dan empati atau perhatian, menurut pernyataan sebagian besar responden alfamart jaksa agung mudah dihubungi, mampu menjelaskan masalah yang dihadapi konsumen, karyawan yang semangat dalam bekerja, karyawan mampu memebikan informasi yang jelas kepada konsumen dan mengucapkan terimakasih setelah transaksi jual beli.

\section{KESIMPULAN DAN SARAN}

\section{Kesimpulan}

Berdasarkan hasil uji analisis data yang telah dilakukan, maka dapat ditarik kesimpulan sebagai berikut :

1. Variabel harga secara parsial berpengaruh positif dan signifikan terhadap kepuasan konsumen, hal tersebut ditunjukkan dari hasil analisis $\mathrm{t}$ test yang menunjukkan bahwa t hitung $=7,645$ dengan nilai Sig $0,000<0,05$.

2. Variabel Kualitas pelayanan secara parsial berpengaruh positif dan signifikan terhadap kepuasan konsumen, hal tersebut ditunjukkan dari hasil analisis $\mathrm{t}$ test yang menunjukkan bahwa t hitung $=3,162$ dengan nilai Sig 0,002 $<0,05$.

3. Variabel Harga dan kualitas pelayanan secara simultan berpengaruh positif dan signifikan terhadap kepuasan konsumen, hal tersebut ditunjukkan dari hasil analisis F test yang menunjukkan bahwa F hitung = 66,870 dengan Sig 0,000 < 0,05. Besarnya pengaruh keseluruhan secara simultan dari variabel harga dan kualitas pelayanan adalah sebesar $56,7 \%$ sedangkan sisanya sebesar $42,4 \%$ dipengaruhi oleh faktor lain yang tidak termasuk dalam penelitian ini.

\section{Saran}

a. Bagi Alfamart J1.Jaksa Agung Suprapto No.11 Mojoroto-Kediri 
1. Karena harga terbukti berpengaruh terhadap kepuasan konsumen, maka pimpinan alfamart jaksa agung mojoroto-kediri harus mempertahankan harga yang sudah ada serta keterjangkauan harga bagi konsumen.

2. Karena kualitas pelayanan terbukti berpengaruh terhadap kepuasan konsumen, maka pimpinan alfamart jaksa agung mojoroto-kediri harus menekankan karyawannya agar meningkatkan dan dan mempertahankan kualitas pelayanan dengan berinovasi memberikan pelayanan yang baikbagi konsumen.

b. Bagi para peneliti selanjutnya

Mengingat masih ada pengaruh dari variabel lain diluar variabel yang ada dalam penelitian ini yakni sebesar $34,13 \%$, maka hasil penelitian ini dapat menjadi bahan untuk melakukan penelitian lanjutan dengan memasukkan variabel lain selain yang sudah adat atau bisa ditambah variabel lagi untuk lebih mengkaji dan lebih menemukan hasil-hasil penelitian yang baru.

\section{DAFTAR PUSTAKA}

Agustina Shinta. 2011. Manajemen Pemasaran. Penerbit Tim UB Press.

Alma, Buchari. 2007. Manajemen Pemasaran dan Pemasaran Jasa. Bandung : Alfabeta.

Arikunto, S. 2010. Metode Penelitian Edisi ke dua. BPFE. Yogyakarta.

Arikunto. 2010. Prosedur Penelitian: Suatu Pendekatan Praktek. Jakarta: Rineka Cipta.

Arikunto,S. 2002. Metodologi Penelitian Suatu Pendekatan Proposal. Jakarta: PT Rineka Cipta.

Djaali,A.(2008). Skala Likert. Yogyakarta : Andi Offset.

Fadlika Yusli dan Harti. Pengaruh Kualitas Layanan dan Harga terhadap Kepuasan Konsumwn di Kolam renang Teuku Umar Bojonegoro. Jurnal Ekonomi.

Griffin, J. 2009. Perspektif Manajemen dan Pemasaran Kontemporer. Erlangga: Jakarta.

Ghozali,i. 2012. Aplikasi Analisis Multivariate Dengan Program SPSS. Semarang: Universitas Diponegoro.

Ghozali,i. 2001. Aplikasi Analisis Multivariate Dengan Program SPSS. Semarang: Universitas Diponegoro.

Ghozali (2014). Pengaruh Kualitas Pelayanan dan Harga terhadap Kepuasan Konsumen pada Expedisi di Surabaya. Jurnal Ilmu dan Riset Manajemen. Vol 3. No.3

Indriyanto san Supomo. 2009. Metodologi Variabel Manajemen, Edisi Pertama. Yogyakarta: BPFE Yogyakarta.

Joko Untoro. 2010. Ekonomi. Jakarta: Kawah Media.

Kotler P. Dan K.L Keller. 2008. Manajemen Pemasaran. Edisi 13. Penerbit Erlangga. Jakarta. 
Kotler, phillip dan Gary Armstrong. 2008. Prinsip-prinsip Pemasaran Jilid 1 edisi ke dua belas. Jakarta : Erlangga

Kotler, Phillip dan Kevin L. Keller. 2009. Manajemen Pemasaran Jilid 1, Edisi ketigabelas. Jakarta : Erlangga.

Kotler, Phillip dan Kevin L. Keller. 2007. Manajemen Pemasaran. Edisi 11. Penerbit Erlangga : Jakarta.

Kristanti, D. (2018). Kebijakan Potongan Harga Dan Volume Penjualan, 16(2).

Lupiyoadi, R. 2011. Manajemen Pemasaran Jasa Teori dan Praktik. Salemba Empat. Jakarta.

Lupiyoadi, R. 2006. Manajemen Pemasaran Jasa. Jakarta: Salemba Empat.

Lupiyoadi R. Dan A. Hamdani. 2009. Manajemen Pemasaran Jasa. Edisi 2. Penerbit Salemba Empat. Jakarta.

Malik, Muhammad Ehsan, dkk. 2012. Impact of Brand image, Service Quality and price on customer satisfaction in pakitan telecomunication Sectpr International. Journal of business and social science.

Pongoh, Melyca Elisabeth. 2013. Kualitas pelayanan1, Kualitas produk dan Harga pengaruhnya terhadap loyalitas pelanggan kartu As telkomsel dikota Manado. Jurnal Emba. Vol. 1 : hal 85-95.

Payne, A. 2010. Pemasaran Jasa. Edisi 1. Andi Offset. Yogyakarta.

Qin, dkk. 2010. Percerived Service Quality in fast food restaurants : empirical evidence from china. International Journal of Quality and Reliability Management. Volume 27. No. 4.

Rangkuty, Freddy. 2006. Measuring Customer Satisfaction. Jakarta: PT. Gramedia Pustaka Utama.

Rao, Purba (2006). Measuring Customer Perception Through Factor Analysis.

Kristanti, D. (2018). Kebijakan Potongan Harga Dan Volume Penjualan, 16(2).

Yunanto, Y. (2017). Pengaruh Kualitias Peayanan Dan Disiplin Kerja Aryawan Biro

Administrasi Umum Terhadap Kepuasan Mahasiswa, 15(2), 99-104. 